At a time when parts of the lay Press are more than usually critical of our profession it seems a pity that these accusations are made by our own colleagues against men and women who also "like time to examine their patients," but do not always find it necessary to exalt their own "professional consciences." -I am, etc.,

Waddesdon, Bucks.

W. A. Bellamy.

\section{Diet and Canine Hysteria}

SIR,-Pyridoxine-vitamin $B_{6}-(J$. Nutrit., 1938, 16, 197) is essential to the dog. Deficiency causes convulsions like epilepsy, dermatitis, and a microcytic hypochromic anaemia (Amer. J. med. Sci., 1940, 199, 518). Treatment with pyridoxine cures. May not this be the cause of canine hysteria or epileptiform fits referred to in Mr. Hamilton Kirk's letter (Feb. 1, p. 200)?-I am, etc.,

Blyth, Northumberland.

\section{A. G. Newell.}

\section{Eye Surgery}

SIR,-I believe there is no doubt as to the validity of the justification which Mr. H. B. Stallard puts forward (Feb. 1, p. 200) for his views on Krönlein's operation and for his statement with regard to the relative radiosensitivity of glioma of the retina as compared with a malignant melanoma of the choroid. Mr. Stallard has taken advantage of opportunities of performing Krönlein's operation which few have had. It is an operation which is not often called for, and I do not doubt that many ophthalmic surgeons of wide experience have never performed it. Mr. Stallard has done a service by bringing forward the advantages and scope of the operation and by describing the technique so clearly.

I should have thought there was no doubt as to the accuracy of the statement : "Malignant melanomata of the choroid are not so radiosensitive as glioma of the retina." The manner in which a retinal glioma can be watched to disappear with the ophthalmoscope is quite remarkable, and the fact that, as $\mathrm{Mr}$. Stallard says, "A retinal glioma has disappeared, and there have been no recurrences in periods up to fifteen years after irradiation; some useful vision has been retained and the child's life saved ..." would seem to justify the use of the term "cure." A number of cases of malignant melanoma of the choroid have been treated by radium, but $I$ believe none has shown a comparable result.-I am, etc.,

Salisbury.

\section{R. Foster Moore.}

\section{Prevention of Rust on Instruments}

SIR,-With reference to the question and answer under the above heading (Jan. 25, p. 168), the inquirer asks whether any substance can be added to boiling water to prevent rusting of instruments during sterilization. The reply is substantially that " there is no time for appreciable rusting to occur" during this process. This statement is incorrect as regards cutting instruments made of a high carbon steel, for example cataract knives, whose edges are rapidly spoilt by corrosion when boiled in $2 \% \mathrm{Na}_{2} \mathrm{CO}_{3}$. While complete protection during water boiling cannot be achieved without using solutions of ammonium or sodium hydroxide (whose carry-over at even small dilutions might damage an eye), it is possible to reduce boiling corrosion to negligible proportions by the use of $2 \%$ A.C.10 emulsified in a $2 \% \mathrm{w} / \mathrm{v} \mathrm{Na} \mathrm{Na}_{3} .10 \mathrm{H}_{2} \mathrm{O}$ solution in water (vide Foster, Le May, and Johnstone, Proc. roy. Soc. Med., 1945, 38, 465). A.C. 10 consists of $95 \%$ of a light petroleum neutral oil and $5 \%$ of a complex of sodium salts of petroleum sulphonic acids. -I am, etc.,

Leeds.

JoHN Foster.

\section{History of Arab Medicine}

SIR,--Had your correspondent, I. B. George (Feb. 1, p. 202), been a little better acquainted with the literature of his subject, he would have known that Dr. Neligan was summarizing (Dec. 14, 1946, p. 919) a passage from the late Prof. E. G. Browne's Arabian Medicine (Cambridge, 1921, p. 2). Here it is :

"When we speak of 'Arabian Science' or 'Arabian Medicine' we mean that body of scientific or medical doctrine which is enshrined in books written in the Arabic language, but which is for the most part Greek in its origin, though with Indian, Persian, and Syrian accretions, and only in a very small degree the product of the Arabian mind. Its importance, as has long been recognized, lies not in its originality, but in the fact that in the long interval which separated the decay of Greek learning from the Renascence it represented the most faithful tradition of ancient wisdom, and was during the Dark Ages the principal source from which Europe derived such philosophical and scientific ideas as she possessed."

Most handbooks of the history of medicine say much the same thing, but it might be objected that most of their authors were not well acquainted with Arabic literature at first hand. Prof. Browne was.

Were it not for your correspondent's onslaught on the late Dr. Neligan, one might take his letter for a hoax. Thus he assures us that the Christian Church regarded belief in infection or contagion as heretical, that only a Moslem physician dared to say that the "black death" was spread by infection and contagion and that he anticipated Pasteur by five centuries. Well, the best contemporary account of the epidemiology of the pestilence of 1347-9 was that of Guy de Chauliac whe observed it in Avignon; his account is reprinted in Haeser's well-known Lehrbuch (vol. 3, pp. 175-6). According to de Chauliac the disease "was so contagious, particularly when there was blood in the sputum (italics mine), that not only by staying with the patient but by merely looking on him one took the disease from another, so that people died without nurses and were buried without priests." Guy de Chauliac was neither a Moslem nor a heretic, but the Pope's own surgeon. The words I have italicized show him to have been a good observer. The plague broke out at Avignon in January, 1348, and was at first primary pneumonic plague. Later in the year it was clinically bubonic plague. The former is of course infectious from person to person, the latter not. It would be interesting to know when the Christian Church decided that it was heretical to believe pestilences were contagious. Isidore, who was, I think, a b:shop, roundly stated (about 700 years before the " black death"): "Pestilentia est contagium quod, dum unum apprehenderit, celeriter ad plures transit." It is hardly necessary to say that what Galen, Isidore, de Chauliac, and the Moslem physician understood by contagion or infection had no relation to Pasteur's doctrine of contagium vivum. The analogy is with the conduction of an electric current or, better, with the sympathetic vibration of a tuning fork picking up its fundamental note. It was, as Prof. Singer pointed out more than thirty years ago, the Italian physician Fracastorius who first took the step of postulating a living contagium. Very few of his contemporaries realized the importance of his suggestion, but, as he dedicated his book to a cardinal, the notion was not regarded as heretical.

I suggest that Dr. Neligan was a good deal better acquainted with the history of medicine than your correspondent.-I am, etc.,

Major Greenwood.

\section{Colonial Medical Service}

SIR,- - In recent months a number of disparaging letters from members of the Colonial Medical Service have appeared in your Journal. Obviously the facts stated were true of particular cases, though they would appear to portray one side of a picture only, to the entire exclusion of the other. These letters might easily have turned me from my decision to join the Service had not I applied out of some sense of vocation.

As a very junior member of the Service, though not so young in the profession, I am not qualified to make generalizations, but for the sake of those who might be deterred in their choice of a career I will record briefly some of my first impressions of work in Africa. Although in a relatively remote outstation, I have found ample scope for my bent, which happens to be surgery, and am already experiencing the truth of a statement made to me on my way out to the effect that "your work will be just what you make it. The natives will soon discover your bent and your abilities or shortcomings, and every case successfully dealt with will inevitably produce two more." This generalization refers equally to preventive medicine, and some of my predecessors have left indelible memorials written on the landscape.

Admittedly administration can be irksome when one would rather give one's time to other calls, but ample time in one's 